\title{
Modification of the indirect haemagglutination test for amoebiasis ${ }^{1}$
}

\author{
IRIS M. KRUPP \\ From the School of Public Health and Tropical Medicine, \\ Tulane University School of Medicine, New Orleans, Louisiana, USA
}

SYNOPSIS Optimal conditions for carrying out the indirect haemagglutination test with sheep erythrocytes were studied using the microtitre system. The age of the erythrocytes, concentration of reagents, time and temperature of tanning, sensitization, and incubation are described with reference to replication of titres. Sera from patients with amoebic colitis were used to evaluate the test conditions.

The haemagglutination test originally described by Kessel, Lewis, Ma, and Kim (1961), and modified by Milgram, Healy, and Kagan (1966), has been used in our laboratory for over three years with sera from patients with clinical amoebiasis and asymptomatic cyst passers. Persons who were negative for $E$. histolytica, but might have had other diseases and/or parasitic infections and were living in an endemic area, were also tested. Replication of titres was not always obtained when the same samples were titrated at weekly or monthly intervals.

An amoebiasis serology evaluation study has been carried on for several years as an informal cooperative effort between several interested investigators working in this field. A comparison of titres obtained by the various investigators, all using the same serum samples, invariably shows wide discrepancies. A possible explanation for this may be the variations in the technique as used by different investigators. These include reaction volume, method of determining serum dilution, concentration of tannic acid, and concentration of sensitized cells. In view of these facts, studies were set up to investigate the factors that affect replication of results and to determine optimum conditions for standardizing the test procedures.

\section{MATERIALS AND METHODS}

SHEEP CELLS Sheep blood ${ }^{2}$ was collected aseptically in Alsever's solution, was received weekly, dispensed into

'This investigation was supported by research grant AI-07374, National Institute of Allergy and Infectious Diseases National I nstitutes of Health.

'Bio Labs, Lafayette, Louisiana.

Received for publication 16 January 1969. sterile vials in 5 millilitre volumes, and stored at $4^{\circ} \mathrm{C}$. Cells were kept sterile during storage, and were put aside for three days before use; thereafter they were used for periods up to two weeks. Erythrocytes from some sheep spontaneously agglutinated when sensitized with $E$. histolytica antigen; only sheep whose blood cells were found to go through the tanning and sensitization procedures without agglutination were used for this study. In preparation for tanning, erythrocytes were washed three times, by centrifugation, in phosphate-buffered saline at $p \mathrm{H} 7.2$ (380 ml of $0.15 \mathrm{M} \mathrm{Na}{ }_{2} \mathrm{HPO}_{4}, 120 \mathrm{ml}$ of $0.15 \mathrm{M} \mathrm{K \textrm {K } _ { 2 }} \mathrm{PO}_{4}$, and $1,000 \mathrm{ml}$ of $0.15 \mathrm{M} \mathrm{NaCl})^{3}$, and a $2.5 \%$ suspension was made after the final washing.

TANNING A stock solution of tannic acid $4(1: 1,000 \mathrm{w} / \mathrm{v})$ in saline was prepared weekly and stored at $4^{\circ} \mathrm{C}$. Dilutions for reaction with erythrocytes were prepared from the stock solution with phosphate-buffered saline at $p \mathbf{H} 7 \cdot 2$. Equal volumes of erythrocyte suspensions and tannic acid solutions were combined in Erlenmeyer flasks and gently rotated at $4^{\circ} \mathrm{C}$ for 20 minutes. After tanning, the cells were washed in phosphate-buffered saline $(p \mathrm{H} \mathrm{7.2)}$. After the second washing the cells were diluted to $2.5 \%$ in phosphate-buffered saline at $p \mathrm{H} 6.4(100 \mathrm{ml}$ of $0.15 \mathrm{M}$ $\mathrm{Na}_{2} \mathrm{HPO}_{4}, 210 \mathrm{ml}$ of $0.15 \mathrm{M} \mathrm{KH} \mathrm{PO}_{4}$, and $310 \mathrm{ml}$ of $0 \cdot 15 \mathrm{M} \mathrm{NaCl}$ ) for sensitization.

SENSITIZATION This was carried out by gently rotating at $37^{\circ} \mathrm{C}$, for 20 minutes, 1 volume of antigen dilution in phosphate-buffered saline, $p \mathrm{H} \mathrm{6.4}$, and 1 volume of $2.5 \%$ tanned erythrocytes. Agamma rabbit serum ${ }^{5}$ was used as a stabilizer in the test and was activated and absorbed with sheep cells before use as described by Bing, Weyand, and Stavitsky (1967). Sensitized erythrocytes were washed twice in $1 \%$ agamma rabbit serum-in phosphate-buffered

Demineralized water was used in all solutions.

Eastman-Kodak Company.

Hyland Laboratories. 


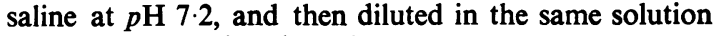
for use on the microtitre plates.

ANTIGEN E. histolytica strain DKB, grown in modified Shaffer-Frye medium with Bacillus symbiosis (Reeves, Meleney, and Frye, 1957), was provided in lyophilised form by $\operatorname{Dr} R$. Reeves of Louisiana State University Medical School, and was kept stored at $-20^{\circ} \mathrm{C}$. Before use the amoebae were reconstituted with saline, $1,000,000$ amoebae $/ \mathrm{ml}$, and stored in $0.5 \mathrm{ml}$ amounts at $-70^{\circ} \mathrm{C}$. This antigen, reconstituted with saline, was further

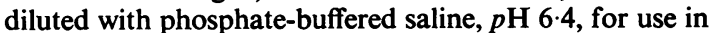
the test. It was found that centrifugation at $18,000 \mathrm{rpm}$ for 20 minutes clarified the antigen and improved the detection of antibodies in test sera. Antigen was diluted $1: 20,1: 40,1: 60,1: 80$, etc, with phosphate-buffered saline, $p \mathrm{H} 6.4$, and combined with equal volumes of a $2.5 \%$ suspension of tanned erythrocytes for sensitization. The sensitized cells were treated with threefold dilutions of reference sera with established titres $(1: 27,1: 729$, and $1: 19,700)$. Serum dilutions were prepared with $1 \%$ agamma rabbit serum and phosphate-buffered saline, $p H$ 7.2. The same reference sera were always used for titration, and the dilution of antigen giving the desired titre with all sera was used for subsequent testing.

TEST SERA Sera collected from patients with amoebiasis and from uninfected persons were centrifuged at 5,000 rpm for 20 minutes and stored at $-20^{\circ} \mathrm{C}$ until used. Sera were heated at $56^{\circ} \mathrm{C}$ for 30 minutes to inactivate complement and were tested for heterophile antibody. If positive, sera were absorbed as described by Bing et al (1967).

TEST SYSTEM The microtitre system was routinely used (Sever, 1962). Of $1 \%$ agamma rabbit serum-7.2 phosphate buffered saline, $0.10 \mathrm{ml}$ was placed into each of the 96 wells on the microtitre plate. ${ }^{6}$ Then $0.05 \mathrm{ml}$ of each serum sample was picked up by Takatsy loops and serially diluted, threefold, in 12 successive wells $(1: 3-$ $1: 532,000)$ and $0.025 \mathrm{ml}$ of a suspension of sensitized cells added to each serum dilution. The plates were sealed with transparent gummed tape, gently rotated for half an hour and then allowed to pattern for several hours at room temperature. The plates were again shaken, placed in the refrigerator overnight, shaken again in the morning and allowed to pattern at room temperature before recording the titre.

\section{RESULTS}

TANNIC ACID Concentrations of tannic acid used were $1: 20,000,40,000,60,000,80,000$, and 100,000 . One volume of cells plus 1 volume of each tannic acid dilution was reacted at $4^{\circ} \mathrm{C}$; one-fourth of the volume was removed at $20,30,45$, and 60 minutes. Cells were washed and sensitized and then reacted with a reference serum with a titre of $1: 6,500$. Parallel experiments were set up, keeping all

${ }^{6}$ Linbro Chemical Company U-shaped, wells of $0.3 \mathrm{ml}$ capacity. conditions constant except that tannic acid dilutions were reacted at $37^{\circ} \mathrm{C}$ instead of at $4^{\circ} \mathrm{C}$. Results for cells processed at $4^{\circ} \mathrm{C}$ are presented in Table I.

\section{TABLE I}

EFFECT OF CONCENTRATION AND TIME OF EXPOSURE TO TANNIC ACID ON SENSITIZATION OF SHEEP ERYTHROCYTES USED IN THE HAEMAGGLUTINATION TEST FOR AMOEBIASIS AS REFLECTED BY ANTIBODY TITRE

\begin{tabular}{|c|c|c|c|c|c|c|}
\hline \multirow{2}{*}{$\begin{array}{l}\text { Time of } \\
\text { Exposure } \\
\text { to Tannic } \\
\text { Acid (min) }\end{array}$} & \multirow[b]{2}{*}{ Reaction ${ }^{1}$} & \multicolumn{5}{|c|}{ Concentration of Tannic Acid (Reciprocal) } \\
\hline & & 20,000 & 40,000 & 60,000 & 80,000 & 100,000 \\
\hline \multirow[t]{3}{*}{20} & $\mathbf{S E}+\mathbf{S}$ & 2,000 & 6,500 & 6,500 & all ++ & 2,000 \\
\hline & $\mathbf{S E}+$ Dil & - & - & - & ++ & - \\
\hline & $\mathrm{TE}+\mathrm{Dil}$ & \pm & - & - & ++ & \pm \\
\hline \multirow[t]{3}{*}{30} & $\mathbf{S E}+\mathbf{S}$ & 2,000 & 6,500 & 6,500 & \pm & 2,000 \\
\hline & SE + Dil & - & - & - & \pm & - \\
\hline & TE + Dil & \pm & - & $\bar{c}$ & \pm & \pm \\
\hline \multirow[t]{3}{*}{45} & $\mathbf{S E}+\mathbf{S}$ & 2,000 & 6,500 & 6,500 & 2,000 & 6,500 \\
\hline & $\mathbf{S E}+\mathbf{D i l}$ & - & - & - & - & - \\
\hline & TE + Dil & - & - & - & \pm & \pm \\
\hline \multirow[t]{3}{*}{60} & $\mathbf{S E}+\mathbf{S}$ & 2,000 & 2.000 & 6,500 & 6,500 & 6,500 \\
\hline & SE + Dil & - & - & - & - & - \\
\hline & $\mathrm{TE}+\mathrm{Dil}$ & - & - & - & \pm & \pm \\
\hline
\end{tabular}

${ }^{1} \mathrm{SE}+\mathbf{S}=$ sensitized erythrocytes + reference serum $\mathrm{SE}+\mathrm{Dil}=$ sensitized erythrocytes + diluent $(1 \%$ agamma rabbit serum-7.2 phosphate-buffered saline)

$\mathrm{TE}+\mathrm{Dil}=$ tanned erythrocytes + diluent ( $1 \%$ agamma rabbit serum$7 \cdot 2$ phosphate-buffered saline)

Cells tanned for 20 and 30 minutes with $1: 20,000$, 80,000 and 100,000 dilutions of tannic acid showed some spontaneous clumping and were very difficult to process. Dilutions of $1: 80,000$ and $1: 100,000$ consistently showed some clumping after tanning. Dilutions of tannic acid of $1: 40,000$ and $1: 60,000$ consistently gave good results. Increasing the time of exposure to tannic acid over 20 minutes did not improve results. With reference to the temperature for tanning there was no difference when cells were tanned at $4^{\circ} \mathrm{C}$ or at $37^{\circ} \mathrm{C}$. The titres of the test serum were similar. However, the patterns of cells tanned at $4^{\circ} \mathrm{C}$ were easier to read than those tanned at $37^{\circ} \mathrm{C}$; the positive and negative patterns were more distinct. Optimum conditions were found to be $1: 60,000$ dilution of tannic acid, tanned at $4^{\circ} \mathrm{C}$ for 20 minutes with constant gentle rotation.

SENSITIZATION All factors of the test were kept constant with the exception that the time and temperature of sensitization of tanned cells were varied from $37^{\circ} \mathrm{C}$ to room temperature. When cells were tanned with a $1: 60,000$ dilution of tannic acid (for 20 minutes, at $4^{\circ} \mathrm{C}$ ), the optimal temperature of sensitization was found to be $37^{\circ} \mathrm{C}$. At this temperature titres were reproducible on subsequent days and titres were higher than they were when cells were 
sensitized at room temperature. Concerning the time of sensitization, the time was varied from 15 to 45 minutes and it was found that the optimum time of sensitization was 20 minutes. When cells were sensitized for a longer period of time, the antibody titres of reference sera decreased.

AGE OF SHEEP Cells All factors in the test were kept constant. The time of storage of the sheep cells (age of cells) used in the test was the only variable. Table II gives the antibody titres obtained with erythrocytes stored under sterile conditions for varying periods of time. Antibody titres were lower when cells older than 20 days were used. A further decrease in titre was noted at $\mathbf{1 0 0}$ days.

\section{TABLE II}

EFFECT OF TIME OF STORAGE OF SHEEP ERYTHROCYTES USED IN THE HAEMAGGLUTINATION TEST

\begin{tabular}{llll} 
Age of Cells (days) & \multicolumn{3}{c}{ Reference Serum Titre } \\
\cline { 2 - 4 } & $1: 320$ & $1: 640$ & $1: 5,120$ \\
\hline 10 & 320 & 640 & 5,120 \\
20 & 320 & 640 & 5,120 \\
30 & 160 & 320 & 5,120 \\
40 & 160 & 160 & 5,120 \\
50 & 160 & & 5,120 \\
60 & 160 & & 5,120 \\
70 & 160 & & 5,120 \\
80 & 160 & & \\
90 & 160 & & 2,560 \\
100 & 80 & & 2,560 \\
110 & 80 & & 2,560
\end{tabular}

Two-fold serum dilutions used.

\section{TABLE III}

HAEMAGgLUTINATION TITRES OBTAINED IN THE MICROTITRE SYSTEM USING THE SAME VOLUME $(0.025 \mathrm{ml})$ BUT DIFFERENT CONCENTRATIONS OF SENSITIZED ERYTHROCYTES WITH SERA FROM PATIENTS WITH AMOEBIASIS

\begin{tabular}{lrr} 
Serum & \multicolumn{2}{c}{ Concentration of Sensitized Cells } \\
\cline { 2 - 3 } Sample & \multicolumn{1}{c}{$1 \%$} & \multicolumn{1}{c}{$0 \cdot 5 \%$} \\
\hline 1 & 729 & 6500 \\
2 & 2,000 & 19,700 \\
3 & 59,000 & 177,000 \\
4 & 2,000 & 6,500 \\
5 & 59,000 & 532,000 \\
6 & 177,000 & 532,000 \\
7 & 19,700 & 177,000 \\
8 & 59,000 & 177,000 \\
9 & 729 & 6,500 \\
10 & 2,000 & 6,500
\end{tabular}

Three-fold serum dilutions used.

EFFECT OF NUMBER OF CELLS ON TITRE Table III presents titres obtained with two cell suspensions, $1 \%$ and $0.5 \%$, with 10 serum samples chosen at random. Results demonstrate that the number of cells is important in replicating antibody titres. The titre is higher when fewer cells are used. The agglu- 0 tination pattern was easier to read and replication of titres was more consistent when a $0.5 \%$ suspension $\frac{\bar{m}}{\partial}$ was used.

OPTIMUM CONDITIONS These have been found to be as follows:

Sheep cells These should be stored at $4^{\circ} \mathrm{C}$ for not $\vec{\omega}$ longer than 20 days.

Solutions All solutions should be prepared with glass-distilled or demineralized water.

Tanning A 1:60,000 tannic acid dilution, $20 \stackrel{\mathrm{N}}{\mathrm{G}}$ minutes at $4^{\circ} \mathrm{C}$ with gentle rotation: both tannic ir acid dilution and cell suspension were precooled to ${ }^{\circ}$ $4^{\circ} \mathrm{C}$ before combination.

Sensitization A cell suspension of $2.5 \%$ in phosphate-buffered saline, $p \mathrm{H} 6.4$, with an equal $\mathbb{\infty}$ volume of antigen, gently rotated at $37^{\circ} \mathrm{C}$ for $20{ }^{\circ}$ minutes. Wash sensitized cells in $1 \%$ agamma rabbit $\stackrel{D}{3}$ serum (absorbed with sheep cells) and use the same $1 \%$ agamma rabbit serum as a stabilizer.

Microtitre system Each well contained $0.05 \mathrm{ml} \vec{\bullet}$ serum or serum dilution, in $0.01 \mathrm{ml}$ of $1 \%$ agamma rabbit serum-phosphate-buffered saline and 0.025 D $\mathrm{ml}$ of a $0.5 \%$ suspension of sensitized cells. Plates are sealed with transparent gummed tape, rotated gently on a serological rotater for half an hour, allowed to remain at room temperature for one to $\mathbb{D}$ two hours and put into the refrigerator overnight. $\overrightarrow{\bar{O}}$ Plates were shaken again in the morning, allowed to repattern at room temperature, and the titres were recorded.

Sera were tested from persons living in Durban, South Africa, where amoebic disease is endemic, $?$ with the following results:

\begin{tabular}{llll} 
Diagnosis & No. of Persons & $\begin{array}{l}\text { Percentage } \\
\text { Positive }\end{array}$ & $\begin{array}{c}\text { Percentage } \\
\text { Negative }\end{array}$ \\
\hline Amoebiasis & 200 & 84 & 16 \\
Cyst passers & 75 & 9 & 91 \\
Uninfected & 117 & 7 & 93
\end{tabular}

\section{COMMENT}

In order to replicate results in the haemagglutination test all of the steps involved must be carefully regulated. Concentration of reagents, time and temperature of tanning, and sensitization were extremely important and variation in any one of these might result in a decrease in antibody titre observed. One ${ }^{\circ}$ of the most important factors is the type of distilled $\underset{\mathbb{D}}{ }$ water used. Only glass-distilled or demineralized $\frac{\rho}{\mathbb{D}}$ water was suitable. Other types of distilled water 
(metal still or reionized water) resulted in spontaneous agglutination of cells after sensitization.

The number of cells used with each serum dilution was also very important in replication of results. Optimal concentration of cells was $0.5 \%(\mathrm{v} / \mathrm{w})$. More cells per well produced a pattern more difficult to read and the titres were often lower than those obtained for a $0.5 \%$ suspension. The use of fewer cells produced patterns that were difficult to read.

Standardizing all the factors described here produced a sensitive test in which titres were reproducible within one dilution.
I am grateful to Miss Elizabeth Maupin for her careful technical assistance.

\section{REFERENCES}

Bing, D. H., Weyand, J. G. M., and Stavitsky, A. B. (1967). Proc. Soc. exp. Biol. (N.Y.), 124, 1166.

Kessel, J. F., Lewis, W. P., Ma, S., and Kim, H. (1961). Ibid, 106, 409. Milgram, E. A., Healy, G. R.. and Kagan, I. G. (1966). Gastroenterology, 50,645 .

Reeves, R. E., Meleney, H. E., and Frye, W. W. (1957). Amer. J. Hyg., 66, 56.

Sever, J. L. (1962). J. Immunol., 88, 320. 